\title{
Business Development of Copyright and Fiduciary Guarantee in Indonesia
}

\author{
Submitted 27/12/19, $1^{\text {st }}$ revision 25/01/20, $2^{\text {nd }}$ revision 28/02/20, accepted 13/03/20 \\ Rinitami Njatrijani ${ }^{1}$, Bagus Rahmanda ${ }^{2}$, Rahandy Rizki Prananda, ${ }^{3}$ \\ Muhammad Nafi Uz Zaman ${ }^{4}$
}

\begin{abstract}
:
Purpose: This study aims to investigate the legal arrangement and procedural challenges in the implementation of copyright as an object of fiduciary guarantee in business development in Indonesia.

Design/methodology/approach: This study was conducted by using empirical juridical method to examine the provisions of Law No. 28 of 2014 regarding the arrangements of copyright as fiduciary guarantee.

Findings: The results showed that the obstacles in realizing copyright as an object of fiduciary guarantee are related to the limited period of protection of intellectual property. Moreover, there is unclear mechanism for determining the assessment of intellectual property assets and the appraisal institutions of intellectual property in Indonesia.

Practical implications: Practically, procedural and technical mechanism between institutions are needed to coordinate institutions, such as Bank Indonesia, Director General of Intellectual Property, Collective Management Institution, creators, artists and public appraisal associations to focus on creating institutions that manage Intellectual Property-based financing.

Originality/value: This paper provides insights on the contemporary business development in Indonesia by examining the role of copyright as an intangible as an object of fiduciary collateral.
\end{abstract}

Keywords: Copyright, fiduciary, business development, legal arrangement.

JEL code: $K 30$.

Paper type: Research article.

\footnotetext{
${ }^{1}$ Universitas Diponegoro, Semarang, Indonesia, email: rinitami.undip@gmail.com

${ }^{2}$ Universitas Diponegoro, Semarang, Indonesia, email: bagrahmanda.undip@yahoo.com

${ }^{3}$ Universitas Diponegoro, Semarang, Indonesia, email: rahandy.undip@gmail.com

${ }^{4}$ Universitas Diponegoro, Semarang, Indonesia, email: muhnafzaman.undip@yahoo.com
} 


\section{Introduction}

Copyright has the broadest scope of protection objects, including science, art and literary works including computer programs. Law No. 28 of 2014 explains that Copyright is the exclusive right of the creator which arises automatically based on the declarative principle after a work is realized in real form without reducing restrictions in accordance with statutory provisions. This Law also includes a new provision in Article 16 paragraph (3) whereby copyright can be used as an Fiduciary Guarantee Object. Copyright Act sates that copyright can be used as an object of fiduciary collateral on the Transfer of Economic Rights related to the regulation of the transfer copyright. Although it has been explicitly stated in the legislation, but the enactment of the article still faces various challenges (Roisah, 2018; Roisah et al., 2018). These challenges are related to the limited period of intellectual property protection, valuation of the economic value of Intellectual Property assets of Copyright and IP appraisal institutions in Indonesia as an appraisal institution that has the ability to provide an assessment of the economic value of Copyright.

The juridical legal framework is an important study of business in Indonesia and is a difficult polemic to implement, considering that fiduciary guarantees still use the legal basis of Law No. 42 of 1999 concerning Fiduciary Guarantees. Technically, the mechanism for implementing Copyright as an object of fiduciary collateral has not been regulated further. This condition poses a significant risk for banks to be able to accept copyright as an object of collateral, while on the other hand the object of copyright is normatively accepted as a debt guarantee in the Indonesian banking sector (Busro et al., 2018). Fiduciary agreements must be made in writing as outlined in a notarial deed and registration is also required. Thus, if a copyright will be used as a fiduciary guarantee, the work must be registered in advance at the Directorate General of Intellectual Property. This registration is important as proof in the event of default, the fiduciary giver is the copyright holder and the execution of the economic value of copyright can be done through a parate executie institution. Based on the background above, this study seeks to discuss obstacles, challenges and opportunities as well as mechanical solutions in realizing copyright as an object of fiduciary object in business development in Indonesia.

\section{Methods}

The method of this research is empirical juridical research using the statutory approach, historical approach and conceptual approach and information search in the field. This research was conducted at the Intellectual Property Directorate of the copyright division, Fiduciary Institutions, Notaries who had made a fiduciary guarantee certificate. Types and sources of data are derived from primary legal materials using the Civil Code, the Commercial Law Code, Law No. 42 of 1999 concerning Fiduciary guarantees, Law No. 28 of 2014 concerning Copyright, Government Regulation No. 21 of 2015 concerning Procedures for Registration of Fiduciary Guarantees and Costs for Making Fiduciary Deed of Assurance. 
Secondary legal material is done by library research or collection of literature through documentary techniques which include study of archives or literature studies such as books, article papers, journals or related works of experts with copyright as an object of fiduciary collateral, regulations, documents, while legal dictionaries, encyclopedias, material available on the internet as tertiary legal material. The data that has been obtained both from literature studies and interviews is also one of the legal material collection techniques that support the documentary techniques in this study and serves to obtain legal material that supports research if needed to then be descriptively analytically analyzed.

\section{Copyright as an Object of Fiduciary Guarantee in Indonesian Legal Arrangements}

Protection of the right to human copyrighted works, including intellectual works, is one of the legally owned assets, often associated with natural law thinking. John Locke (1823) presented the concept of ownership as a property in relation to human rights regarding life and liberty. Here, every individual has a natural right to have fruit in his business by intellectual property right (Baldwin and von Hippel, 2010).

According to the theory of natural law, the creator has the moral right to enjoy his creation, including the profits generated by his intellectual (Dreyfuss, 1987; Hasibuan, 2003). The rationale given to an individual for legal protection of his creation is inseparable from the dominance of the thought of the Natural Law School which emphasizes the human factor and the use of reason as is known in the civil legal system. The legal tradition of the Common Law System is called functionalist justification, as an incentive system that protects copyright as an economic instrument to increase knowledge and support social economic development.

As a copyright's system, the starting point of protection is given to the object of copyright work. For this reason, creation must always have its fixation, while originality and creativity with a degree that is not too high. Restricted rights apply to restricted works that may not be carried out by the public in connection with the work, except for fair dealing or fair uses (Lewisky, 2004). The Common Law system only recognizes economic rights, while moral rights are being discussed (Lewinsky, 2004; Janed, 2014).

Copyright is an exclusive right originating from and to protect the creator or right holder, so that other people cannot use it or are prohibited from using it except with the permission of the creator as the copyright owner or the person receiving the rights holder, which holder copyright that is not the creator only has a part of the exclusive rights, namely only in the form of economic rights. According to the Civil Law System, copyright protection gives the creator exclusive rights to do anything about his creation, except those specified in the limitation rules (Janed, 2014). 
Copyright provides protection for the creator in the personal and intellectual relations of his work and to utilize his work. This means that copyright protection has a moral right that arises from the personal and intellectual relationship of the creator with his creation, and has an economic right dimension related to the use or exploitation of his creation in accordance with the norm that copyright protected protect the author with respect to his intellectual and personal relationship with his work and also with respect to his utilization of his work (Lewinsky, 2004). Copyright can be transferred or transferred either in part or in whole, through 2 ways of transfer and assignment.

The use of copyright as a fiduciary guarantee is inseparable from the characteristics of the object of fiduciary collateral is an object that has economic value in the sense that one day if the debtor cannot repay his debt the object can cover the debt. Objects that can be used as fiduciary collateral include movable and immovable objects (Fuady, 2003). In relation to copyright, copyright has moral rights and economic rights so that it is possible to use it as a fiduciary guarantee.

Moral rights are the rights inherent eternally in the creator to keep his name on the copy in connection with the use of his creation for the public. Economic rights are the exclusive rights of the creator or copyright holder to obtain economic benefits for a work. The fiduciary giver is an individual or corporation that owns the object that is the object of fiduciary collateral, while the fiduciary recipient is an individual or corporation that has receivables for which payments are guaranteed with fiduciary guarantee (Salim, 2011).

The new provisions regarding copyright can be used as fiduciary guarantees in the copyright Act No. 28 of 2014 is a facilitative accomodation from the government to the community in providing a forum for business development to improve community welfare as a form of appreciation that has been realized in tangible form (Badriyah et $a l ., 2019)$. This is in line with the principle of reward theory / incentive theory, namely the granting of exclusive rights in the form of legal protection for a certain period so that the creator can exploit the work he produces as an appreciation for his efforts and sacrifices that have been made in creating his work.

\section{Characteristics of Copyright and Fiduciary Guarantee Mechanisms}

Law No. 28 of 2014 concerning Copyright stated that copyright is an intangible movable object as also contained in Article 511 of the Civil Code. Hasibuan (2008) adds that copyright is a property right to which the properties of property rights as stipulated in civil law. Article 1 paragraph (4) of Fiduciary Law No. 42 of 1999 states that objects which are objects of fiduciary collateral are all things that can be owned and transferred, both tangible and intangible, registered or unregistered, movable or non-registered immovable property that can be mortgaged. It can be transferred only to its economic rights, while moral rights remain attached to the creator (Saidin, 2013). 
Transfers of copyright may be transferred in part or in whole as stated that the economic rights of a Work remain in the hands of the Author or the copyright Holder as long as the Author or the copyright Holder does not transfer all economic rights of the Author or the copyright Holder to the recipient of the transfer of rights to the Work. The transfer of copyright in its entirety can be caused by inheritance, grants, endowments, wills, written agreements or for other justified reasons in accordance with statutory provisions. Article 18 of the copyright Law No. 28 of 2014 explicitly explains that copyrights can be traded.

However, the article protects the creator from a sold-out system. In general, regarding the binding of fiduciary guarantees according to the Fiduciary Collateral Act according to Government Regulation Number 21 of 2015 concerning Procedures for Registration of Fiduciary Guarantees and Costs for Making Fiduciary Deed Guarantees, Items that can be burdened with fiduciary guarantees have characteristics that can be owned and transferred legally, tangible or intangible which will be obtained later, moving and not moving. Other characters are objects that already exist and objects that will be the object of fiduciary collateral, while the fiduciary recipient is obtained later. These objects can also be on units or types of objects, and can also be on more than one type or unit of objects including the results of objects that have become objects of fiduciary collateral as well as the results of insurance claims from objects that are objects of fiduciary collateral.

For inventory objects, stock trading, the fiduciary giver is an individual or corporation that owns the object that is the object of fiduciary collateral, while the fiduciary recipient is an individual or corporation that has receivables for which payments are guaranteed with fiduciary collateral (Salim, 2005). The mechanism for binding fiduciary guarantees includes making a fiduciary deed before a notary and the deed is registered at the Fiduciary Registration Office which is part of the General Law Directorate, Ministry of Law and Human Rights, paying the fiduciary guarantee registration fee, and issuing a fiduciary guarantee certificate that contains an executorial title.

In the fiduciary guarantee deed and fiduciary guarantee certificate contained the value of the object and the guarantee value of the object of the fiduciary guarantee. In assessing objects used as collateral so far the lender uses the services of a public appraiser in the financial sector to provide an assessment of the economic value of objects. Intellectual Property Rights Certificate is currently not included in the list of collateral referred to in the provisions of Bank Indonesia Regulation Number 15 / PBI / 2012 concerning Assessment of Commercial Bank Asset Quality (Article 43).

Therefore there is no financial institution that accepts copyright as collateral, although legally it can be used as an object of fiduciary collateral as stipulated in article 16 (3) of Law No. 28 of 2014. As a comparison, several countries have implemented and capitalized copyright as fiduciary. Singapore which in 2019 through Singapore Brand Finance already $64 \%$ of the country's corporate value is intangible assets through the 
Intellectual Property Office of Singapore (IPOS) (Singapore Brand Finance, 2019), while the US Brand Finance by $91.2 \%$, and UK Brand Finance by $89 \%$, which is a institutions that manage financing based on intellectual property rights.

\section{Conclusion}

This study highlights that barriers internally and externally in realizing copyright as an object of fiduciary collateral in business development in Indonesia include: the absence of appraisal institutions that assess the determination of economic value in determining the price of a copyright by fiduciary and banking institutions. And there are no juridical institutions in the form of implementing regulations related to Intellectual Property assets in the form of copyright which can be used as collateral for fiduciary objects. The solution offered in overcoming the aforementioned obstacles is the need for the establishment or empowerment of a financial institution based on Intellectual Property to maximize the work of copyright which can be guaranteed through fiduciary to support the business development in Indonesia.

In addition, it is also necessary to study legal arrangements and procedural and technical mechanisms by comparison in other countries as a solution that has imposed copyright as a fiduciary guarantee, in order to be able to predict the value of copyright to be guaranteed. Indonesia needs to try to establish an Intellectual Property-based financing institution eelating to execution mechanisms and regulations about the valuer of copyright assets. Fiduciary institutions need to get ready to accept copyright as objects of debt guarantees whose guarantor institutions are fiduciary institutions.

\section{References:}

Badriyah, S.M., Suharto, R., Susilowati, E., Allam, M.H.F. 2019. Execution of fiducia guarantee in government pawnshop companies in Semarang city. International Journal of Recent Technology and Engineering, 8(4), 4196-4200.

Baldwin, C.Y., von Hippel, E.A. 2010. Modeling a paradigm shift: From producer innovation to user and open collaborative innovation. Harvard Business School, Finance Working Paper, (10-038), 4764-4809.

Busro, A., Sulistianingsih, D., Adhi, Y.P., Pujiono. 2018. Quo Vadis copyright as fiduciary guarantee in Indonesian legal arrangement. Journal of Legal, Ethical and Regulatory Issues, 21(2).

Dreyfuss, R.C. 1987. The creative employee and the Copyright Act of 1976. The University of Chicago Law Review, 54(2), 590-647.

Fuady, M. 2003. Fiduciary Guarantee [Indonesian]. Bandung, Citra Aditya Bakti.

Government Regulation No. 21 of 2015 concerning Procedures for Registration of Fiduciary Guarantees and Costs for Making Fiduciary Deed Guarantees.

Hasibuan, H.D.E. 2003. Brand Protection (Study of United States Decisions) [Indonesian]. Jakarta, Faculty of Law, University of Indonesia.

Hasibuan, O. 2008. Copyright in Indonesia: special review, song copyright, neighboring rights, and collecting society [Indonesian]. Bandung, Alumni.

Janed, R. 2014. Copyright's Law. Bandung, Citra Aditya Bakti.

Law of the Republic of Indonesia Number 28 of 2014 concerning Copyright. 
Law of the Republic of Indonesia Number 4 of 1996 concerning Mortgage Rights.

Law of the Republic of Indonesia Number 42 of 1999 concerning Fiduciary Guarantees.

Lewinsky, S. 2004. European Copyright"s Law. Lecturer notes on Training in the framework of cooperation between the European Union and Asian Community in the Field of Intellectual Property Rights (European Community and ASEAN Intellectual Property Right's Co-operation Programme-ECAP II), EPO in collaboration with the Max Planck Institute, Germany.

Locke, J. 1823. Two Treaties of Government: Chapter V of Property. Londong, Sharpe and Son.

Najoan, R.F. 2016. Legal Review of Copyright as a Fiduciary Guarantee, Lex et Societatis [Indonesian]. Manado, Universitas Sam Ratulangi.

Roisah, K. 2018. Employee-inventor's right to compensation in patent law system in Indonesia and some countries. Journal of Advanced Research in Law and Economics, 9(7), 2415-2424.

Roisah, K., Setiyono, J., Prananingtyas, P., Farida, E. 2017. Trends of global values in legal political formation of intellectual property law in Indonesia. International Journal of Civil Engineering and Technology, 8(9), 391-397.

Saidin, O.K. 2013. Transplantasi Hukum Asing ke Dalam Undang-undang Hak Cipta Nasional dan Penerapannya Terhadap Perlindungan Karya Sinematografi (Studi Kritis Terhadap Dinamika Politik Hukum Dari Auteurswet 1912 ke TRIPs Agreement 1994) (Doctoral dissertation, Dissertation, Doctoral Program, Law Faculty, Universitas Sumatera Utara).

Salim, H.S. 2005 Development of Guarantee Law in Indonesia [Indonesian]. Jakarta, Raja Grafika Persada.

Salim, H.S. 2011 Introduction to Written Civil Law (BW) [Indonesian]. Jakarta, Sinar Grafika.

Setianingrum, R.B. 2017. Determining Mechanism of Appraisal Value and Binding of Copyright as Fiduciary Assurance Objects [Indonesian]. Media Hukum, 23(2), 229-238.

Singapore Brand Finance. 2019. The Intellectual Property Office of Singapore (IPOS). Retrieved from https://brandfinance.com/knowledge-centre/reports/brand-financesingapore-100-2019/.

United States Brand Finance. 2019. Brand Finance's Brand Strength Index Places Deloitte. Retrieved from https://brandfinance.com/knowledge-centre/reports/brand-financeus-500-2019/.

United Kingdom Brand Finance. 2019. UK's Fastest Growing Brand. Retrieved from https://brandfinance.com/knowledge-centre/reports/brand-finance-uk-150-2019/. 